Volume 5, Issue 2

\title{
A Review of the Property Data Challenge in Nigeria
}

\author{
Ndubisi Onwuanyi ${ }^{1}$ \\ ${ }^{1}$ Department of Estate Management, University of Benin, Benin.
}

To cite this article: Onwuanyi, N. (2020). A Review of the Property Data Challenge in Nigeria. Journal of African Real Estate Research, 5(2), pp.15-40. DOI: 10.15641/jarer.v5i2.842.

\begin{abstract}
Data on Nigeria's property sector tends to be inadequate and inaccessible. While the government produces statistics for its own activities, such as GDP and inflation rates, other sectors function with insufficient information. This is particularly true for Nigeria's property sector and its data which have been given a lesser status despite an increasing economic importance for investment opportunity, GDP contribution and attraction of foreign investment funds. The gap in data creates a challenging situation for property valuers, but also, an opportunity for property researchers. This paper, which reviews existing literature on the subject, is a contribution to the debate as well as an effort towards a solution. The literature stipulates that poor accessibility to property data leads valuers to enact coping mechanisms rather than best practice and that property data is synonymous with market transactions which makes it invaluable to valuers. Also, there is a convergence of views in the reviewed literature that a central data bank offers opportunities for a solution. Conversely, it is here argued that focusing on market transactions is a narrow understanding of data as property data extends beyond such transactions. This school of thought believes that the users and uses of property transaction data extend beyond valuers and valuations and that the central data bank recommendation requires examination as to its feasibility. Accordingly, this paper broadens the definition of property data by recognising the existence of non-market data, by identifying its other users and uses as well as its role in socio-economic policies. The considerable doubts associated with the central data bank recommendation leads the study to make recommendations which are novel, but nevertheless, hold holistic methods for addressing Nigeria's property data challenge.
\end{abstract}

Keywords: Property Data; Market Transparency; Property Markets; Nigeria

\footnotetext{
${ }^{1}$ ndubisi.onwuanyi@uniben.edu
} 


\section{Introduction}

Access to reliable and valid data continues to be a challenge in Nigeria. Population censuses, for one, have been the centre of statistical controversy (Kazeem, 2019), and these recurrent disputes have engendered unfavorable perceptions of data produced in Nigeria. Adepoju and Olaomi's (2008: p.231) state that: "the general attitude towards Nigerian statistical data is that they are unreliable and unusable". This critical assertion is substantiated by Olubusoye et al. (2015: p.12) who observe "a poor statistical culture, a lack of feel for numbers and generally a lack of appreciation of the important role which statistical data and information can play in society". Consequently, the country relies upon data estimates and forecasts which have typically and consistently come from global institutions such as the International Monetary Fund and The World Bank (Kazeem, 2019). The consensus across academia and recent assessments of the challenges related to Nigerian data (Nwogu, 2006; Olubusoye et al. 2015; Beguy, 2016; Afeye, 2019; Kazeem, 2019; Uduu, 2020) is that data is not easily available due to systemic deficiencies mainly of governance (poor coordination, inadequate monitoring and evaluation) and funding (which is largely-donor driven).

This study is about property data, a variant of mainstream data, a universal need which has been described as "the world's most valuable resource" of the digital era (Economist, 2017: p.1). Across the economies of the world, property investments create, preserve and enlarge wealth as well as protect it against inflationary pressure. As a consequence, the greatest part of global wealth is held in the form of property (World Bank, 1989), and property is the world's largest asset class by value (Savills World Research, 2017). Furthermore, property data is important in the economy where it is the norm for value-creating production decisions to be made at various levels: the individual, household, producer and government. These decisions are indirectly dependent on property data because property is a basic production input (Jin et al., 2018). Fraser (1984) underscores the inter-reliance between property markets and the economy. Property data is also important because it is economic data which makes it a vital input to property investment decisions. At governmental level, property data is also essential to economic planning and management. All of these highlight the importance of property data in various decision making processes which have significant economic impact. This requires that property data be accessible and reliable. It is particularly important in the preparation of valuation advice for the guidance of property investors whose decisions should be optimal, and therefore, founded upon optimal valuation advice.

Like in other countries, property markets are a central component of Nigeria's economy. Correspondingly, property data is of significance to the functioning and efficiency of Nigeria's property market. Having reliable and accessible data will support optimal property investment decisions which, by producing successful outcomes, offers the potential to strengthen the economy. Hence, without accessible and reliable data to facilitate accurate valuations, optimal investment advice cannot be given by valuers (Ajibola, 2010; Adegoke, 2016). Many authors have highlighted the existent data inadequacy for 
property valuations in Nigeria (Ogunba \& Ajayi, 1998; Olaleye, 2004; Aluko, 2007; Effiong, 2015; Obayomi, 2018). The Jones Lang LaSalle (JLL) Global Real Estate Transparency Index (2018) also underscores this view by its finding that Nigeria has "a low transparency" which diminishes its global competitiveness. This low international perception of Nigeria's property market is due partly to a "data availability" challenge (JLL, 2018), and may slow down property sector growth (Gbonegun, 2018).

This study, therefore, examines the challenge of accessible and reliable data to Nigeria. It involves a review of extant research work on property data inadequacy in the country. The available body of work is limited and it is entirely the output of valuers, who collectively, are an important segment of regular users of property data. The paper finds it necessary to broaden the property data concept to accommodate the omissions observed in existing research. This is then used to elucidate the extent of the challenge by identifying the various groups who usually have a need for, or are involved in the production of, property data. Furthermore, this study collates the various recommendations as per the articles reviewed. Areas of commonality were critically appraised in the search for a holistic solution.

Following the introduction, there is a review of literature on mainstream data, its uses, challenges and their consequences in developed and developing countries. This is followed by the definition of property data and an elucidation of the concept in Nigeria's context. Thereafter, the nature of the property data challenge in Nigeria is defined from local and international perspectives as a foundation to the review of extant research. The specifics and recommendations of the reviewed works are then collated and the common recommendation discussed with the intention of proposing a holistic solution to the Nigerian property data challenge.

\section{Literature Review}

According to the RICS (2009), "Data can be in the form of facts or statistics" (RICS 2009: p.4). The meaning here is that "facts" are known to be real and experientially provable whilst "statistics" constitute numerical information which is obtained from a process involving collection, organization, analysis, and interpretation. Thus, data may be gathered either directly from observation (including surveys and measurements) or produced by statistical analysis. Irrespective of the origin, data consists of evidentiary details about people, assets, events, issues and phenomena. It is purposely sought because it is needed to produce understanding, and thereby, provide the basis for reference and analysis. Good quality data should have the features of reliability and validity. Reliability, as Burns (2000) states, calls for dependability, stability, consistency, predictability and accuracy. Validity would exist if data reflects accurately what it ought to reflect. This depends on methodology. 


\subsection{Data in a Universal Context}

Data is a universal resource. Its significance can be appreciated from two distinct levels; the corporate level and at the level of economic management. For firms, businesses and other organisations which are guided by set targets, data is important because it "is the basis of analysis. Data is used for benchmarking, business planning, decision-making, and internal and external reporting. Its target users will be just as varied. This makes it difficult to identify exactly why data is needed-specific decisions will require specific sets of data" (RICS, 2019: p.7). As a business tool, data is powerful and possesses the potential to create value. It offers cost savings through improved efficiency and provides customer need insights. For these reasons, data is profitable to produce, to possess and to use. At the level of economic management, data constitute the input which are used to measure economic development (Ge \& Harfield, 2006). Data is essential for governments and institutions to plan accurately, fund and evaluate their activities, and in monitoring progress towards specific goals of improving socio-economic conditions (Beguy, 2016).

\subsection{Data Challenges and their Consequences}

Where information is relevant, reliable, recent and valid, it improves the prospects of making the right decision (Burns, 2000). Thus, data inadequacy presents a challenge - one which requires persistent research for sources with greater detail as well as improved accuracy. The search for new, improved, data-gathering systems is necessitated by the growing expectations of data users and the complexity of decision-making (McAfee \& Brynjolfson, 2012). Big data, a new source facilitated by the digital revolution, is one of these systems. It is data which is accumulated from diverse sources which practically cover all aspects of life and living (Mutuku, 2016). It consists of "new data sources other than censuses and surveys which have been common in official circles" (Beresewicz, 2015: p.2). In big data, developed and emerging countries can obtain diversified and detailed information with the potential to enable improvements in virtually all aspects of society and the economy. Although big data has gained wide recognition as a potential source of statistical information, Beresewicz (2015: p.8) cautions that "there are several aspects that need to be considered in order to meet the criteria of a statistical data source".

There are opportunities in big data for less developed countries and these consist of new opportunities for statistical tracking, measurement and delivery of more information for planning and management (Beresewicz, 2015). Some of these opportunities are in property or real estate. Big data applied to real estate furnishes information for more effective marketing and improved buyer decision-making; enables investor choice-making as to the best locations for projects where customer traffic maximisation is important; enables easier identification of trends and more accurate predictions. Also, there are advantages of user-convenience and quick information delivery due to big data's extensive volume, variety, veracity (accuracy), velocity (speed), and therefore value (Özköse et al., 2015). Furthermore, big data facilitates 
automated valuation models and enables faster decisions by buyers and sellers (Kok et al., 2018). It also aids the provision of cost-efficient urban services by obtaining information on citizen preferences (Barkham, 2015). The benefits of big data extend to property owners, property investors and property practitioners. However, this digital resource requires facilitation by high levels of digital literacy and internet penetration because it is an interactive undertaking, necessitating public input. Africa's comparatively low levels of internet penetration (Statista, 2019a), low adult literacy (World Bank, 2018a) and a poor statistical culture (Beguy, 2016) are potential barriers to big data. Nigeria's population is given as 195 million (an estimate, incidentally, in the absence of a census), the adult literacy rate is $62 \%$ (World Bank, 2018a); the level of internet penetration is $68.82 \%$ (Statista, 2019); whilst the number of Nigerians on social media networks is $16.6 \%$ (Statista, $2019 \mathrm{~b}$ ). Much growth may not be achieved in the short and medium terms due to various estimates of rising poverty levels (African Development Bank, 2018; WorldBank, 2018b). Big data, as a resource of the future for Nigeria and other developing countries, may have limited impact unless these constraints are addressed.

\subsection{Data in Developed and Developing Countries}

Countries of varying levels of development need data. For developing countries, data is critical to development whilst developed countries are increasingly becoming data-centric as their technology-driven firms explore the benefits of digital capital (Singh, 2019). This has seen them become top producers of data in what is termed as the new data economy. Data is described as the fuel of this new economy (Chakravorti et al., 2019), because it is used to create new goods and services as well as solve problems (Aaronson, 2020). Developing countries need data in order to make realistic plans. They need to produce indices which define social and economic life. These include births and deaths, growth and poverty, taxes and trade, land and the environment, health, schooling and safety. But the quality of data is dependent upon national statistical systems which, in the case of Africa are ineffective, making it difficult to have accurate, timely and reliable data (Beguy, 2016). The inability of African countries to produce frequent and timeous data creates a challenge to data-driven decisions (Beguy, 2016). In developed countries, the availability of capacity for the operation of statistical systems has provided "leadership, policy direction, forward planning...operational standards and methodological criteria" which have created successful outcomes, although some systems are notably more successful than others (OECD 2015: p.6). The need for data is underscored by the fact that socio-economic development is planned with data, tracked by data and periodically measured by data. Thus, undertaking development without data is akin to going on a distant journey without a map.

\subsection{The Concept of Property Data}

Property data is data which is gathered or produced from landed property. It originates from landed property as it passes, at different times, through the processes of being initially delineated, bought and owned, leased out and sold 
off. These processes involve administration which deals with rights, tenure, registration and transactions-monitoring (Wallace, 2009); and management, development and disposal (by sale or letting) which are value-adding, market and profit-oriented (Darlow, 1984; Fraser, 1984; Savills UK, 2020). Due to factors of heterogeneity and uniqueness of location, each property unit is distinct (Fraser, 1984). This necessitates its clear identification and collection and retention of pertinent details for reference and analysis as may become necessary. Using the RICS (2009) definition of property data as consisting of facts and statistics, it becomes evident that some statistical information will emanate from within the property market whilst other factual information regarding property will originate from outside it. Therefore, this study espouses a broad concept of property data which constitutes three categories: property ownership data, property market data and property industry data as displayed in Table 1. The various types of data in each category and their sources are listed. In the first category, property ownership data is not marketderived; rather it comes from the land administration system. In the second category, property market data emanates from the property market with the exchange of rights in property between buyers and sellers, and lessors and lessees in the letting, investment and development sectors. As Fraser (1984) explains, rents are determined in the rental sector; investments are bought and sold in the investment sector, whilst in the development sector site values are determined as well as the supply of new property for sale and lease. Between these three sectors, there are interactions which give character to the property market.

Table 1 shows that the property industry is a larger and wider concept than the property market; the latter being a part of the former. The RICS (2009) report recognises this fact by its focus, not directly on the UK property market, but on the UK property industry which "concerns almost every aspect of the built environment: from how we use and interact with properties as individuals and businesses, through to how a building's energy consumption and construction details are being recorded and analysed to help surveyors, asset managers, building managers, developers and investors make informed decisions about real estate" (RICS, 2009: p.3). Just as in the case of the three sectors of the property market, there is an interrelationship between the three data types described in Table 1 . They jointly create a basis for optimal decision-making in the entire property industry. The true source of reliable and valid property data is the individual and unique property asset. That uniqueness can be captured under the three identified types and sources. Property data is mostly a cumulation of information gathered from heterogeneous property units spread across a particular jurisdiction. 
Table 1: A Broader Conception of Property Data

\begin{tabular}{|c|c|c|}
\hline \multicolumn{3}{|c|}{ Types of Property Data } \\
\hline Data on Property ownership & Data from Property market & Data on Property industry \\
\hline $\begin{array}{l}\text { name of owner } \\
\text { geographical location } \\
\text { land size } \\
\text { date of construction } \\
\text { title/tenure }\end{array}$ & $\begin{array}{l}\text { asking prices } \\
\text { biding prices } \\
\text { transaction/traded prices } \\
\text { transaction rents (occupied) } \\
\text { transaction rents (new) } \\
\text { investment expectations }\end{array}$ & $\begin{array}{l}\text { material costs } \\
\text { labour costs } \\
\text { building supervision costs } \\
\text { professional fees } \\
\text { input to decision-making }\end{array}$ \\
\hline \multicolumn{3}{|c|}{ Sources of Property Data } \\
\hline land registration system & $\begin{array}{l}\text { the property market's letting, } \\
\text { investment and development } \\
\text { sectors, real estate } \\
\text { agents/brokers, valuation } \\
\text { advice/reports }\end{array}$ & $\begin{array}{l}\text { the market for building materials, } \\
\text { building industry regulations, } \\
\text { construction industry professionals } \\
\text { (architects, builders, quantity } \\
\text { surveyors, civil engineers, from self- } \\
\text { builders, estate developers }\end{array}$ \\
\hline
\end{tabular}

Source: Author's Research, 2020

Table 1 addresses the systematic accumulation of property data which is the main issue of this study. It also seeks to explain that property data is not synonymous with property market data. Thus, it is emphasised that property data extends beyond what is supplied by, or obtained from, the property market. That property data accumulation in the Nigerian context refers to three categories: data collected under the statutory system at Land Registries in Ministries of Lands and Survey, market data and industry data. This provides the background for elucidating the various users and uses of data. However, it is pertinent here to differentiate between formally accumulated property data (which is under consideration in this study) and valuation data, whose sources RICS (2017: p.17) identifies as: "the client; inspections; property analysis; market analysis and the public". This definition is rationalised by the fact that: "the valuation process begins from the moment the client requests a valuation, up till the value is established and reported" (RICS, 2017: p.17).

\subsection{The Property Data Challenge in Nigeria}

Since this paper discusses the property data challenge in Nigeria, it is appropriate to consider what evidence there is that such a challenge actually exists. The issue can best be addressed by looking at the present sources of data and the flow of information in Nigeria's property market in contrast to property markets in other countries.

Property data is obtainable in Nigeria in the three categories as shown in Table 1. Not all land is registered, nor are all land transactions recorded. Research by Butler (2009; 2012) and Akinbogun and Dunse (2014) respectively confirm widespread informality in, and the immaturity of, the Nigerian market. Informality is not associated with record-keeping whilst immaturity implies a lack of organisation. Under these subsisting conditions, 
there is no systematic collation of transaction evidence from the property market and this affects data adequacy and accessibility (Olapade et al., 2019). The situation in Nigeria is worsened because most transactions do not pass through valuers mainly because they are not adequate for the volume of transactions and this creates an opportunity for intrusion by non-professionals (Oloyede, 2011). Regarding what this paper describes as property industry data, Nigeria is not completely in the dark as some records are independently held by individual practitioners, firms, professional and other organisations and government agencies, but since this is not systematic, the results are unlikely to be comprehensive. Therefore, the main property data source is the property market. This is the common origin of data held in valuation firms' own records, presented in research reports and published by the media. It is also the source of data which is purveyed by a growing number of online sources. These include Proshare, Estateintel, Nigerian Property Centre and Castlesweekly. Reports on market trends and opportunities have also been produced by firms such as $\mathrm{PwC}$, Banwo and Ighodalo and Akin Olawore \& Co.

The issue of market information flow is addressed by the JLL 2016 and 2018 global surveys of property markets. These are important assessments because globalisation has inevitably engendered comparisons between economies, property markets and systems. In JLL's (2016) survey, the dearth of data contributed to the low (opaque) rating given to Nigeria's property market mainly because of its inability to meet a global standard measure of market transparency. Nigeria's 96 th position out of 97 countries indicates a very low perception of its property market by international investors. In the 2018 JLL Index of Global Real Estate Markets, "data availability" (a property market issue) is one of the criteria, others being institutional issues such as "governance, transaction processes, property rights and the regulatory/legal environment". Out of 100 countries and 168 city markets, Nigeria undergoes an improved rating as 67 th out of 100 . Its overall ranking improved to that of a "low transparency". It can be surmised that the limitations experienced locally in terms of data sources and the conclusions from the JLL surveys confirm the existence of a property data challenge in Nigeria.

In response to this historic deficit in statistics and data, Nigeria recently adopted counteractive measures which include the establishment of the Nigerian Bureau of Statistics (NBS) in 2007 and the Office of StatisticianGeneral. These were done to meet the challenge of producing official statistics in Federal Ministries, Departments and Agencies (MDAs), State Statistical Agencies (SSAs) and Local Government Councils (LGCs). The NBS is part of the World Bank-funded Statistical Master Plan (2003). It has, despite a paucity of resources, improved the efficiency and timeliness of data production as well as the supply when compared with its predecessors, the Federal Office of Statistics and National Data Bank. The NBS as the main agency responsible for official statistics, coordinates the entire Nigerian National Statistical System and is required to produce adequate, quality and timely official statistics to meet the needs of government, universities, research institutes, the private sector and international agencies. 


\subsection{The Importance of Data in Property Markets}

Property markets are made up of parties who engage mainly in buying, selling, leasing, mortgage and development of landed property. These activities tend to involve sizable monetary outlays since property investment is essentially a way of holding money. Again, market transactions present the basis for appropriately rewarding the factors of production (Harvey, 1994)landed property is a factor input to all productive activities (Jin et al., 2018). For all these reasons, it is important that neither party to a property transaction spends more or receives less than he ought. Thus, where data is inadequate for quality advice on value, there is a likelihood that transactions will not be based on optimal prices. The outcome will be an unequal exchange of value, which is indicative of a market system which is inefficient and of low competitiveness (NASDAQ, 2020). Where factors of production are able to receive a commensurate return, such a market would be described as being allocatively, operationally and informationally efficient, and therefore, competitive (Keogh \& D'Arcy, 1994).

The importance of data is reflected also by the fact that the modern economy is substantially driven by an effective and efficient property sector which, in turn, is driven by data. The property sector is vital for many reasons. First, shelter is a basic human need. Second, real estate (including land) accounts for a substantial portion of national wealth (World Bank, 1989). Such wealth is the outcome of investment decisions which are made and sustained by information. The financial importance of real estate leads Kok et al. (2018: p.202) to describe it as the "largest asset class in the world". Third, landed property is a factor input to production, meaning that goods produced by industries and services delivered by businesses are enabled by the property industry (Minguzzi, 2018). Fourth, the property industry (and its constituent construction sector) employs professionals, artisans and other workers who contribute to economic output and the GDP (Minguzzi, 2018). Fifth, real estate offers a stable base for revenue yield to the government through taxation (Youngman \& Malme, 2005). Data contributes to the effectiveness and efficiency of the property sector by facilitating and optimising buyer and seller decisions (Kok et al., 2018), promoting transparency and a good market reputation, both at home and abroad (Kelly, 2018).

\subsection{Data Challenges and Property Markets in Nigeria}

The common manifestation of the data challenge in Nigeria's property market is the scarcity of reliable and valid data when and where it is needed. This is an inference drawn from existing research (see Ajibola, 2010; Ajibola \& Ogungbemi, 2011; Adegoke, 2016; Olaleye \& Olapade, 2018). A further challenge exists if the data needed is either not available or is available only in a limited quantity, a situation which gives rise to data sharing (Olapade \& Olaleye, 2018). Another complication might be that available data is not recent. This scenario leads to the adoption of methods which do not require comprehensive market data (Ashaolu \& Olaniran, 2016) Furthermore, the data challenge leads valuers to seek the assistance of colleagues who usually have privately garnered such information (Ashaolu \& Olaniran, 2016; 
Olapade \& Olaleye, 2018).This course of action constitutes a challenge because it is not standard practice and data may be unreliable (Bamigbola, 2018). Furthermore, there may be a reluctance to share due to the undoubtedly competitive nature of practice. Thus, data becomes a trade secret of those who have privately gathered it. This situation has implications for the quality of valuation advice given by valuation firms. Thus, the shortage of data, by hampering property investment advice, would tend to delay new investments as valuers need to gather the information for investors privately. A failure to do this effectively may discourage investors. The data challenge impacts property markets because property investment is based upon expectations of the future in respect of which the present is used as the basis of analysis. Data represents reality, so its unavailability makes the future more risky.

Various deficiencies of Nigeria's property market have contributed to its categorisation as an immature sector by researchers such as Akinbogun and Dunse (2014) and Clement et al. (2016). One of these deficiencies is a dearth of data. At the core of this challenge is the absence of an efficient institutional framework and workable arrangement for the systematic collection and dissemination of property data (Bamigbola, 2018; Olapade et al., 2019). The suggestion is that the Nigerian system is comparatively inchoate and in need of organisation, re-organisation and standardisation. The current situation is unsatisfactory because it is reasonable to expect that Africa's largest economy would be supported by an efficient data management of its property sector which is vital to economic production. However, Nigeria falls behind the Republic of South Africa (second largest economy in Africa) in property data collation, dissemination and property market transparency (JLL, 2018). The latter has a well-established and effective system of capturing data on all property ownership and changes thereof (Luus, 2003). Under this system, house price indices are regularly produced and metropolitan authorities capture data on property within their jurisdictions. Unmistakably, this suggests a property data system which has taken shape and form. This is confirmed by JLL's (2018) categorisation of South Africa as Africa's most transparent market, ranking higher than eight European countries including Austria, the Czech Republic, Norway and Portugal. The disparity between Nigeria and South Africa cannot be explained simply by South Africa's relatively longer period of political and economic stability. Good planning, management and supporting legislation are also important factors. These should not continue to elude Nigeria.

The absolute necessity for change is further rationalised by the growing importance of Nigeria's property sector. Its contribution to GDP has been rising; with an increase in foreign real estate investment and real estate's national appeal as an investment opportunity. This is reflected by the listing of property development companies on the Nigerian Stock Exchange and various speculative residential and commercial development projects in major cities. As mentioned, data is pivotal to an efficient property industry given the industry's substantive role in economic development. The real benefits of a well-run property sector are more likely to materialise if property practitioners, property investors and policy makers (and managers) have access to adequate, timely and valid property data. Therefore, the resolution 
of the property data challenge in Nigeria serves the mutual interests of all participating actors, as well as society, more broadly. In these many respects, it becomes undeniably necessary, important and apposite to examine the property data situation in Nigeria.

This paper, therefore, examines the challenge which property data poses to Nigeria by undertaking a critique of published literature on the subject to ascertain:

(i) The specifics of property data inaccessibility;

(ii) The recommendation(s) for overcoming property data inaccessibility; and consequently; and

(iii) Evaluating the feasibility of the recommendation(s) with a view to proposing a holistic solution which addresses all issues pertinent to resolving the property data challenge in Nigeria.

\section{Approach}

The research approach of this study involves a review of extant literature on the accessibility of property data in Nigeria. A total of 23 publications on the topic were found through an exhaustive online search. In the absence of a property research repository, this was a reasonable method of assembling published work on the topic. Given that property data in Nigeria is limited, this paper surveys the work of valuers who are both producers and users of the data. Their perspectives, given this dual role, therefore adequately reflects the nature of the challenge and contributes towards its resolution. The papers reviewed are empirical studies undertaken between 1998 and 2019, a period spanning 21 years. Out of the 23 studies, 21 are Nigerian, the remaining two are Ghanaian. They have been included for their relevance which arises from the fact that both countries are facing the same challenge. The fact that a solution is yet to be found and property data inaccessibility continues to be a topic of debate underscores its importance in Nigeria. Thus, this approach elucidates the concept of property data; identifies its present sources in Nigeria; and addresses the nature of the property data challenge. Thereafter, extant research is reviewed with the main recommendation(s) collated for discussion. This aims to support the search of a holistic solution which aligns with this paper's working definition of property data, through which explorations of ways of overcoming the challenge are presented.

The research which is of relevance to the property data challenge is displayed in Table 2 which lists the year of publication, the researcher(s), the essentials of the studies and their shared recommendation.

Table 2: List of Published Property Data Research

\begin{tabular}{|l|l|l|l|l|}
\hline S/N & Year & Author(s) & Specifics & $\begin{array}{l}\text { Common } \\
\text { Recommendation }\end{array}$ \\
\hline 1 & 1998 & $\begin{array}{l}\text { Ogunba, A.O.\& } \\
\text { Ajayi, C.A. }\end{array}$ & $\begin{array}{l}\text { Residential valuation inaccuracies in Lagos result from } \\
\text { the dearth of data, amongst other factors. }\end{array}$ & A central NIESV* databank. \\
\hline
\end{tabular}




\begin{tabular}{|c|c|c|c|c|}
\hline 2 & 2004 & Olaleye, A. & $\begin{array}{l}\text { An investigation of data sources of valuers and the } \\
\text { effects of the lack of a data bank in Nigeria }\end{array}$ & A centralised databank. \\
\hline 3 & 2006 & Mends, T.M. ** & $\begin{array}{l}\text { Conditions and contradictions, namely data and } \\
\text { knowledge inadequacies, market informality, amongst } \\
\text { others, often distort estimated property values. }\end{array}$ & $\begin{array}{l}\text { A sound property data system } \\
\text { is recommended, inter alia. }\end{array}$ \\
\hline 4 & 2007 & Aluko, B.T. & $\begin{array}{l}\text { Some factors, inclusive of a lack of a centralised } \\
\text { databank, cause variations in valuers' interpretation of } \\
\text { property characteristics which affect valuation output. }\end{array}$ & A centralised databank. \\
\hline 5 & 2008 & Olaleye, A. & $\begin{array}{l}\text { The dearth of transaction data limits choice and strategy } \\
\text { in the portfolio approach to property investment }\end{array}$ & A centralised database \\
\hline 6 & 2010 & Ajibola, M.O. & $\begin{array}{l}\text { Inaccurate professional advice is greatly affected by } \\
\text { lack of a databank. }\end{array}$ & A NIESV databank. \\
\hline 7 & 2010 & $\begin{array}{l}\text { Ajibola, M. O. \& } \\
\text { Oloyede, S. A. }\end{array}$ & $\begin{array}{l}\text { Lack of data sharing is a major barrier to valuation } \\
\text { consistency. }\end{array}$ & A central NIESV databank. \\
\hline 8 & 2011 & $\begin{array}{l}\text { Ajibola, M.O.\& } \\
\text { Oletubo, A.A. }\end{array}$ & $\begin{array}{l}\text { Valuation inaccuracy in Lagos is due to inadequacy of } \\
\text { data, outdated methods, inexperience and client } \\
\text { influence. }\end{array}$ & A central NIESV database. \\
\hline 9 & 2011 & $\begin{array}{l}\text { Babawale, G.K.\& } \\
\text { Omirin, M.M. }\end{array}$ & $\begin{array}{l}\text { High levels of inaccuracies in residential property } \\
\text { valuations are due to factors such as experience and } \\
\text { market knowledge. }\end{array}$ & $\begin{array}{l}\text { Systematic data procurement } \\
\text { and banking by NIESV. }\end{array}$ \\
\hline 10 & 2011 & $\begin{array}{l}\text { Ajibola, M.O.\& } \\
\text { Ogungbemi, A.O. }\end{array}$ & Valuation inconsistencies are linked with poor data. & An NIESV databank. \\
\hline 11 & 2015 & Ayedun et al. & $\begin{array}{l}\text { Variance and inaccuracy attributable to inexperience, } \\
\text { training and a data dearth. }\end{array}$ & A central database. \\
\hline 12 & 2015 & $\begin{array}{l}\text { Bello, V.A. \& } \\
\text { Thomas, O.J. }\end{array}$ & $\begin{array}{l}\text { Valuation opinion amongst valuers show close and } \\
\text { insignificant differences; but databank is a necessity }\end{array}$ & A central NIESV databank. \\
\hline 13 & 2015 & Effiong, J.B. & $\begin{array}{l}\text { Valuation variances and inaccuracies in Nigeria are } \\
\text { comparatively far higher than in the UK. }\end{array}$ & A central property database. \\
\hline 14 & 2016 & Adegoke, O.J. & $\begin{array}{l}\text { Variance and inaccuracy cause fluctuation in the price } \\
\text { of property, sending wrong signals. }\end{array}$ & A data bank system. \\
\hline 15 & 2016 & $\begin{array}{l}\text { Ashaolu, T.A.\& } \\
\text { Olaniran, M.O. }\end{array}$ & $\begin{array}{l}\text { Data difficulties drive valuers to seek assistance from } \\
\text { colleagues or adopt less than ideal methods. }\end{array}$ & A central NIESV databank. \\
\hline 16 & 2016 & Clement et al. & $\begin{array}{l}\text { Lagos' property market is comparatively more mature } \\
\text { than Ibadan and Oshogbo; but all are challenged by } \\
\text { market data. }\end{array}$ & $\begin{array}{l}\text { An NIESV databank for each } \\
\text { state. }\end{array}$ \\
\hline 17 & 2017 & Adebayo, A.A. & $\begin{array}{l}\text { The availability of data determines valuers' adopted } \\
\text { method of valuation. }\end{array}$ & $\begin{array}{l}\text { None, but recognises pivotal } \\
\text { role of data. }\end{array}$ \\
\hline 18 & 2017 & $\begin{array}{l}\text { Awuah, K.G.B. et } \\
\text { al. ** }\end{array}$ & $\begin{array}{l}\text { Identifies and assesses reliability of seven valuation data } \\
\text { sources in Ghana. }\end{array}$ & $\begin{array}{l}\text { Systematic data collection } \\
\text { needed. }\end{array}$ \\
\hline 19 & 2018 & $\begin{array}{l}\text { Olapade, D. \& } \\
\text { Olaleye, A. }\end{array}$ & $\begin{array}{l}\text { Identifies and explains } 19 \text { factors affecting valuers' data } \\
\text { access in the Lagos market. }\end{array}$ & $\begin{array}{l}\text { A data bank can address } \\
\text { challenge. }\end{array}$ \\
\hline 20 & 2018 & Aliyu et al. & $\begin{array}{l}\text { Identifies data inadequacy amongst others as causative } \\
\text { factors of mortgage valuation inaccuracy in Kaduna. }\end{array}$ & A databank. \\
\hline 21 & 2018 & $\begin{array}{l}\text { Olapade, T.O. \& } \\
\text { Olaleye, A. }\end{array}$ & $\begin{array}{l}\text { Most Lagos valuers are willing to share data and support } \\
\text { a data bank as a means of improving accessibility. }\end{array}$ & A central database. \\
\hline 22 & 2018 & Bamigbola, D. & $\begin{array}{l}\text { Deployment of technology by valuers is associated with } \\
\text { absence of a data bank. }\end{array}$ & $\begin{array}{l}\text { A database system involving } \\
\text { individuals/groups/institutions }\end{array}$ \\
\hline 23 & 2019 & Olapade et al. & $\begin{array}{l}\text { Valuers, as potential users of centralised property } \\
\text { database, would prefer its management by NIESV. }\end{array}$ & An NIESV central databank. \\
\hline
\end{tabular}


*NIESV: The Nigerian Institution of Estate Surveyors and Valuers

**Ghanaian Study

Source: Author's Research, 2020

\section{Overview of Property Data Research in Nigeria}

For three basic reasons, these collated studies all deal with valuation. First, the authors are all trained valuers and real estate practitioners. Secondly, "data plays a central role in the real estate sector and the valuation process" (RICS, 2017: p.17) and finally, research relating to property data in Nigeria is held by valuers.

\subsection{Valuation Accuracy and Valuation Variance}

Valuation accuracy and variance are key areas of investigation. Valuation inaccuracy is seen to emerge if there is a wide difference between the assessed market value of a property and its eventual sale price; where no market or material changes have taken place to warrant any difference (Ibiyemi, 2013). On the other hand, valuation variance occurs where valuations of the same property, for the same purpose, and at the same time, differ significantly amongst different valuers (Ibiyemi, 2013). Variance differs from inaccuracy because it assesses the degree of divergence in opinion of value amongst different valuers whilst the latter reflects divergence from actual market value. The recommendations of researchers (see for example Ogunba \& Ajayi, 1998; Olaleye, 2004; Aluko, 2007; Effiong, 2015) on these two issues indicate a commonality of opinions in support of a centralised property data bank managed by the Nigerian Institution of Estate Surveyors and Valuers. This common recommendation points at data input as a factor in inaccuracies and variances.

Despite the distinction made between inaccuracy and variance, the commonality of opinions on data banking suggests that they are two sides of the same coin. Given the call for valuation standards by Effiong (2015), data banks alone cannot guarantee that valuations will be more accurate, but they may bring about a reduction in these occurrences (Ajibola, 2010). If a valuation was analogous to a manufactured product such as a medical device which must be safe and effective in use, its successful making would require a combination of quality control and quality assurance in accordance with good manufacturing practice (ISPE, 2020). In this instance, the undoubted determinants of quality control are input (in the form of valid data) and processing (in the form of methodology) whilst quality assurance comes in the shape of adherence to prescribed valuation standards, including the valuer's interpretation of market facts, an exercise which requires skill and experience. Ceteris paribus, the inference can be made that all accurate and consistent valuations have a common origin in good data. This position is supported by the RICS (2017: 17): "Data quality has a direct impact on valuation accuracy, and it must therefore be reliable, accurate and openly available, and lastly, secure as the corruption of data is increasingly becoming an issue". Therefore, data inadequacy is a challenge to accurate and consistent valuations. 


\subsection{Data Sharing Among Valuers}

Data-sharing refers to data which was gathered privately by individual firms who willingly share with colleague firms (Olapade \& Olaleye, 2018). Their research indicates a preponderance of firms which are willing to share data. However, this does not stop the firms from desiring a central databank, suggesting that sharing is only a means of coping. Sharing raises the issue of reliability as data gathered at the level of the individual firm will tend to be limited in scope and application. Bamigbola (2018) disapproves of valuers' reliance on "individual market surveys" because it is not standard practice. Such data may be unsuitable because every property market consists of many sub-markets where differences may exist, meaning that datasets from one sub-market may not apply to others.

\subsection{Valuers'Accessibility to Data}

Despite the inevitable resort to data sharing, valuers' access to this data option depends on certain factors, the most important being confidentiality (Olapade \& Olaleye, 2019). Given that data is a sought after resource, firms may be unwilling to share it and potentially lose their competitive advantage. The next two most important factors which limit accessibility are the lack of cooperation (a reluctance to share), followed by the accuracy level of the data (Olapade \& Olaleye, 2019). This suggests a further limitation to data sharing. In Ashaolu and Olaniran's (2016) study of Ibadan and Abeokuta, participants' responses to the data gap were either to share or use valuation methods which do not require comprehensive market data. This confirms that valuers face difficulties due to poor data accessibility which can change only if data becomes easily accessible.

Awuah et al.'s (2017) property market study in Ghana is relevant here because both Ghana and Nigeria were ranked as "opaque" markets in the 2016 JLL survey. JLL's classifications of the world's property markets are in five categories starting from "opaque" at the very lowest to "highly transparent" at the apex. In-between, in ascending order, are "low transparency", "semitransparent" and "transparent". Classification of a particular market as opaque means that its processes are adjudged to be near the lowest level on the scale of transparency used in the assessment. This would be due to deficiencies in the main areas of regulatory control, ease of doing business, use of technology and the availability of industry information to guide investors. In 2018 Ghana remained "opaque" whilst Nigeria moved up to a "low transparency" status. Awuah et al. (2017: p.448) reflect on the data challenge by stating that, "reliable property market information represents a major barrier to improving valuation practice in Ghana and it is regarded as a key challenge". Data sources on Ghana's property market consist of: valuers' own database; public institutions; professional colleagues; property owners; estate developers; estate agents; and the media. This is akin to Nigeria where valuers' colleagues are the most sought-after data source. In Ghana, valuers' own datasets were considered to be the most reliable, with the media being the least reliable. Again, the distinction between data availability and data reliability is highlighted here because the RICS (2009) report emphasises that "sharing data is still a major challenge for the 
industry...There is the ever-present challenge of seeking consistent and trusted data" (RICS, 2019: p.17).

\subsection{Summary of Findings}

The literature review reveals the following. Firstly, transaction information on Nigeria's property market is scarce. This leads to a reliance on individual or businesses' data collection systems and data sharing (Ashaolu \& Olaniran, 2016; Olapade \& Olaleye, 2018). Secondly, the focus of all the studies on property market transactions data appears to suggest that all property data originates from the property market. This does not align with the analysis in Table 1. Thirdly, all the studies focus on the impact of property data inaccessibility on valuers. Whilst this is understandable because the authors are valuers, it is, nevertheless, not all-embracing because such data is used by other publics such as government, corporate concerns, voluntary organisations, donor and aid organisations, foreign and local investors, media, research organisations and the public.

Fourthly and finally, all 23 property research works, except one, make the same recommendation for a central data bank. However, the feasibility and modality remain unaddressed. Thus, no attention has been given to the efficient accumulation of data in a market whose "low transparency" categorisation connotes inefficiency. Olapade et al. (2019) are the exception, but do not go into much detail. In addition to these identified gaps in literature, other issues which are important to an all-embracing property data collation system which need to be addressed are as follows:

(i) Market size, sectors, segments and activities; spatial variations; trends in returns/prospects.

(ii) The existence and activities of producers of property industry data.

(iii) The data needs of non-valuers.

(iv) The existence and role of non-market property data sources.

These are considered in Section 4.5.

\subsection{Accumulating Data on Omitted Issues in Nigeria's Property Data Research}

Table 3 lists the important property industry issues identified in Section 4.4 which have not received much research attention in Nigeria. The dearth of information on these areas effectively constitutes a data gap. They cover market specifics (Column 1), non-market data sources (Column 2), property industry data producers (Column 3 ) and the needs of data users who are nonvaluers (Column 4). These issues need more research attention because the wide, consistent and regular availability of such data will reduce the considerable data gap in the Nigerian property industry. The table explains the scope of each data type and its relevance to justify inclusion in a holistic 
collation system with the potential to contribute towards uplifting the reputation of Nigeria's property market.

Table 3: Data on Omitted Issues

\begin{tabular}{|c|c|c|c|c|}
\hline Issue & $\begin{array}{c}\text { Market } \\
\text { Overview (1) }\end{array}$ & $\begin{array}{c}\text { Non-Market } \\
\text { Property Data (2) }\end{array}$ & $\begin{array}{l}\text { Property Industry Data } \\
\text { Producers (3) }\end{array}$ & $\begin{array}{c}\text { Non-Valuers Who } \\
\text { Need Property Data } \\
\text { (4) }\end{array}$ \\
\hline Scope & $\begin{array}{l}\text { Comprises sizes of } \\
\text { key sectors(letting, } \\
\text { development \& } \\
\text { investment); vacancie } \\
\text { s; } \\
\text { unsold/unlet property } \\
\text { etc. }\end{array}$ & $\begin{array}{l}\text { Comes from property } \\
\text { owners, estate } \\
\text { developers, self- } \\
\text { builders \& the wider } \\
\text { property industry }\end{array}$ & $\begin{array}{l}\text { Comes from individuals, analysts, } \\
\text { media, researchers, organisations } \\
\text { who present alternatives. e.g. the } \\
\text { Ronald Igbinoba Real Foundation for } \\
\text { Housing and Urban Development } \\
\text { (2019) which provides housing } \\
\text { market analytics }\end{array}$ & $\begin{array}{l}\text { Include financiers \& } \\
\text { mortgagees, } \\
\text { policy makers, } \\
\text { international \& donor } \\
\text { agencies, } \\
\text { researchers/analysts }\end{array}$ \\
\hline Relevance & $\begin{array}{l}\text { Provides highlights; } \\
\text { indicates trends; } \\
\text { promotes } \\
\text { transparency; } \\
\text { enhances market } \\
\text { image indicates } \\
\text { trends; creates } \\
\text { investor confidence }\end{array}$ & $\begin{array}{c}\text { May support/ } \\
\text { complement other } \\
\text { data with relevant } \\
\text { information }\end{array}$ & $\begin{array}{l}\text { Helps to broaden the horizon; an } \\
\text { alternative data source for investors }\end{array}$ & $\begin{array}{l}\text { These groups are } \\
\text { interested in house } \\
\text { prices, a better } \\
\text { knowledge of real } \\
\text { estate and credit } \\
\text { market conditions, } \\
\text { economic policy \& } \\
\text { financial stability } \\
\text { monitoring. Real } \\
\text { estate significantly } \\
\text { affects the real } \\
\text { economy }\end{array}$ \\
\hline
\end{tabular}

Source: Author's Research, 2020

Further comments about the table are as follows. The issues listed in columns 1 and 2 are within the province of the valuer. Whilst the valuer has little to do about the issues in column 3, it is important for him to be aware that there are producers of such data which could be useful to the valuer as the valuer's could be to such data producers. Regarding column 4, the valuer should be aware as a producer of analytical data, that processed information from the market and entire industry is used as input by non-valuers to whom such data should be available.

\subsection{Feasibility, Modality and Achievability of a Central Data Bank}

Other research identifies conditions in, and characteristics of, Nigeria's property market which constitute hindrances to data collection (Butler, 2009; 2012; Akinbogun et al., 2014). It is natural to imagine either the federal government or the valuers' professional body as potential handlers of a property data bank, however, there are reasons which suggest their unsuitability. Government involvement may lead to availability at best, but may not deliver validity, timeliness and reliability. Available data that is untrustworthy, is of very little worth or use. There are reasons to believe that the administrative and fiscal centralism which Nigeria started operating post1966 has not served it well as a way of organising society and economic 
activity. Some researchers find this federalism to be excessively bureaucratic, wasteful and inefficient. For example, Asobie (1995: p.158), describes the system as a "centralised federalism" which, being a negation of true federalism, "has not aided the process of national development" (Asobie, 1995: p.158). In the assessment of Nwosu (2016), there is too much waste at the centre where government has too much money at its disposal, having saddled itself with too many responsibilities, few of which it is able to perform well. Perhaps the most telling description of the incapacity at the centre is Nigerian President Olusegun Obasanjo's 2000 justification of the privatisation of federal government enterprises on the grounds of excessive bureaucratic control, gross incompetence, mismanagement, corruption and complacency (5CCPress, 2007). These are reasons for caution as government has a history of not being business-minded. Furthermore, if property markets are indeed local in nature and Nigeria is a federal system, centralising locally collected data creates an unnecessary level of bureaucracy. Effectiveness and efficiency of the NBS data collection on the economy is threatened by inadequate funding but also poor institutional capacity (Kazeem, 2019). Other NBS challenges are the timeliness of output dissemination, cost inefficiencies arising from overlaps amongst the various public sector data producers, causing poor coordination (horizontal and vertical) as well as feedback from local and state governments (Olubusoye et al., 2015). Being a subclass of economic data, property data collection and dissemination by the government could be prone to similar challenges. Government incapacity is indicated at the sub-national level by its inability, since the 1978 Land Use Act, to discharge its exclusive responsibility of accumulating property ownership data.

The following reasons raise doubt regarding the capacity of the Nigerian property profession to handle the responsibility solely. Firstly, its involvement may be limited to property market transactions data for which it would have to rely totally upon the participation of registered members of the NIESV. Secondly, in a country of an estimated 195 million people, the property profession is only 16,000-strong with 1,000 registered firms (NIESV, 2020). This suggests that it would be unrealistic for the NIESV professional membership to deliver the volume of transactional data required to make a significant difference, given the prevalence of unregistered transactions and brokers.

\subsection{Recommendations Arising from the Review}

The main finding from the review is that a central data bank is the preferred solution to data inaccessibility in Nigeria. The other findings are inferences drawn from the review. These include the notion that property data is assumed to be a need of valuers only, so data inaccessibility is a challenge to valuers only; and that property data is synonymous with market data. The last three points are issues which have been explained in the process of defining the property data challenge. The issues to which they give rise are explained in Table 3 in section 4.5. Thus, the main finding and recommendation in the review is the establishment of a data bank. 


\subsubsection{Considerations for a data banking system for Nigeria}

Since the Nigerian system has not been successful at accumulating property data, it is prudent to learn from arrangements in successful countries, particularly in the Western world which tend to have more advanced data infrastructure. The countries selected are the UK, USA, Finland and France. The UK and USA are good examples because they are respectively the first and third most transparent property markets in the world; for which data accessibility is a main classifying factor (JLL, 2018). France and Finland are additional representatives of continental Europe. Table 4 compares the ways in which the three property data types are accumulated and disseminated in these western countries.

\section{Table 4: Basis of Accumulation and Dissemination in Some Western Countries}

\begin{tabular}{|c|c|c|c|c|c|}
\hline \multicolumn{6}{|c|}{ Types of Data } \\
\hline \multicolumn{2}{|c|}{ Land \& Property Registration } & \multicolumn{2}{|c|}{ Property Value } & \multicolumn{2}{|c|}{ Property Industry } \\
\hline \multicolumn{6}{|c|}{ Basis of Accumulation and Dissemination } \\
\hline Central & Non-Central & Private & Public & Private & Public \\
\hline France & UK & UK & UK & UK & UK \\
\hline \multirow[t]{2}{*}{ Finland } & Northern Ireland & $\begin{array}{l}\text { Northern } \\
\text { Ireland }\end{array}$ & $\begin{array}{l}\text { Northern } \\
\text { Ireland }\end{array}$ & $\begin{array}{l}\text { Northern } \\
\text { Ireland }\end{array}$ & $\begin{array}{l}\text { Northern } \\
\text { Ireland }\end{array}$ \\
\hline & USA & USA & USA & USA & USA \\
\hline
\end{tabular}

Source: Author's Research, 2020

Table 4 shows that the UK, USA and Northern Ireland have non-centralised registration unlike France and Finland. Property value data is available from private and public sources in all the countries. In the UK, the RICS is a private source of data whilst "in terms of public sources of property value data...the Inland Revenue offers online tabulations of property transactions (Calhoun (2001: p.18). The UK provides an example to Nigeria because its overall effectiveness is illustrated by the relative accuracy and consistency of its valuations, as revealed by Effiong's (2015) UK-Nigeria comparative study on variances and inaccuracies.

\subsubsection{A contextual solution}

In learning from established systems, evolving systems should be circumspect and avoid making the assumption that one-size-fits-all. This suggests that they should take into consideration their socio-political environment and lived experience. Thus, a feasible data bank system for Nigeria should truly reflect the requirements of the environment. As such, the design should comprise the necessary elements which would work to create the best possible chances for successful operation in the existent circumstances. This would require that existing deficiencies be overcome and known pitfalls avoided. In this regard, the two important considerations are as follows. Centralisation should be avoided because of its predisposition towards becoming a bureaucracy. Additionally, Nigeria's sub-national governments' very limited success at discharging their statutory responsibility for formal land registration advises that other options be 
explored. The fact that 42 years have elapsed since that responsibility was given to them under the 1978 Land Use Act is sufficient evidence of their limitations. This leaves for consideration the third tier of government: the local government system.

It is espoused that a great potential for success lies in organising property data collection and dissemination on a local government basis across the entire country. Many reasons can be adduced in support of this proposition. First, every landed property belongs to a locale. Second, property markets are local in nature. Third, property is locally developed and put to use in the locality where it stands. Fourth, local governments have a grassroots presence which places them in a position to monitor their environment more closely than the state and federal governments. Fifth, the local government system, as a creation of the constitution, can be legally and financially empowered for property registration and associated activities. Understanding the potential in local governments requires looking beyond the past and present failures of the system which is a creation of military fiat just like the under-performing state government system. The modality by which the local government system can accomplish property data management is beyond the scope of this paper. However, the promise which the system holds is evident from the capacity of colonial era city councils to perform effectively some functions which are now the responsibility of state governments.

\section{Conclusion}

This paper evaluated the challenge of property data inaccessibility and inadequacy in Nigeria. The approach involved a critique of existing literature, which incidentally, all concentrate on property market data and on valuers as users of data. This further involved identifying the studies' specifics and evaluating their recommendations with the ultimate objective of making a holistic submission. The conclusion suggests that the property data challenge in Nigeria extends beyond property market data which is but one of three categories of property data identified in this study. Furthermore, it indicates that besides valuer-users, the challenge extends to other users and uses of data which need to be addressed by the data banking solution unanimously recommended in the literature.

The findings suggest that existing research is not all-embracing in the following ways. First, its focus on property market transactions data is conceptually narrow because property data extends beyond market transactions. Furthermore, the challenge is examined only from the viewpoint of valuers and valuations whereas the users and the uses of property data extend beyond valuers and valuations. Finally, the studies do not examine the feasibility and modality of the common recommendation for a central data bank. Also the findings reveal the extent of the property data gap in Nigeria.

The findings of the study contribute to an improved knowledge of property data in Nigeria by expatiating the concept and the extent of the challenge. This raises the expectation that efforts will be intensified towards a holistic solution. In addition, the findings highlight the value of property data as an 
input to economic policy and its potential to impact the entire property industry and macro economy. Reliable and valid data are therefore essential for accurate valuations, optimal property investment advice and the sector's success at large. An investment in a consistent data system will likely improve the performance and reputation of Nigeria's property industry, which in turn serves the mutual interests of property practitioners, property investors and policy makers. Finally, the research suggests that a sustainable solution to the property data challenge in Nigeria should be contextual. Knowledge of practices elsewhere is important and may be helpful, but whatever is proposed as a Nigerian solution must fit the Nigerian situation.

The study recommends the establishment of data banks, not one data bank but rather many to reflect the country's federal nature. Local government should manage the data for its region given that property is a fixed resource and belongs to a locale. Since local presence can compel a wider compliance, local governments should take over responsibility for property registration from states, and become the custodians of property ownership data, property market data and property industry data. Furthermore, a statistical culture should be promoted by legally requiring all who buy, sell or lease property (individuals, households and other economic actors) in a locality to supply relevant property market data to the local government registry. In addition, online access to these records should be available so that valuers can gain direct access whilst analysts may collate the figures to produce overviews and statistics on regional and sectoral trends, rent indices and market analyses. Beyond these recommendations, ultimately overcoming the property data challenge would depend principally on reforms targeted at the inefficiencies of Nigeria's property industry, particularly widespread property market informality and bureaucratic capacity.

Undeniably, Nigeria's 36 sub-national units have failed to accumulate property ownership data significantly in the 42 years since the 1978 Land Use Act. The necessity of a workable arrangement for property industry data makes it pertinent that further research be made as to whether advantage lies more in maintaining the status quo ante or in embracing change by evaluating the feasibility of entrusting that responsibility (including property transactions and property ownership data) to a rejuvenated and empowered local government system.

\section{References}

Aaronson, S.A. (2020). Data as a Development Issue. Project: Data Series. Centre for international Governance Innovation. CIGI Papers N0.223, July 2019. [Online]. Available at:

https://www.researchgate.net/publication/341090961 Data Is a De velopment Issue (Accessed: 11 November, 2020).

Adebayo, A.A. (2017). The Influence of Data Availability on Valuation Methods in Nigeria: Behavioural Practice of Estate Surveyors and Valuers. In: Emerging Issues in Urban Land Use, Management and 
Development in Nigeria, M. B. Nuhu, M.T.A. Ajayi, I.A. Olatunji \& N. B. Udoekanem (Eds.), 399-417, University of Abuja Press.

Adegboye, K. (2019). Hope for Real Estate Investors as the Sector's Growth Potentials Thrive. Vanguard, April 21. [Online]. Available at: https://www.vanguardngr.com/2019/04/hope-rises-for-real-estateinvestors-as-sectors-growth-potentials-thrive/(Accessed: 5 July, 2020).

Adegoke, O.J. (2016). Effects of Valuation Variance and Inaccuracy in the Commercial Property Market: An Empirical Study. Journal of Property Investment and Finance, 34(3), pp.270-292.

Adepoju, A.A. \& Olaomi, J.O. (2008). An Appraisal of Statistical Data Management in Nigeria: Case for a Reliable Statistical Information System. The Social Sciences, 3(3), pp.231-234.

Afeye, T. (2019). Nigeria's Data Problem and Why It Is a Big Deal. [Online]. Available at: https://medium.com/datadriveninvestor/nigerias-dataproblem-and-why-it-is-a-big-deal-514d43e604f (Accessed: 14 October, 2019).

Ajibola, M.O. (2010). Valuation Inaccuracy: An Examination of the Causes in Lagos Metropolis. Journal of Sustainable Development, 3(4), pp.187-193.

Ajibola, M.O. \& Ogungbemi, A.O. (2011). Importance of Accessibility to Reliable Data for Real Estate Practice. Mediterranean Journal of Social and Sciences, 2(2), pp.223-231.

Ajibola, M.O. \& Oletubo, A.A. (2011). Assessment of Accuracy of Valuation in the Property Market in Lagos Metropolis. Global Journal of Engineering and Technology, 4(1), pp.45-51.

Ajibola, M.O. \& Oloyede, S.A. (2010). Data Sharing: A Critical Factor for Estate Surveying and Valuation Practice in Nigeria. Global Journal of Engineering and Technology, 3(1), pp.61-69.

Akinbogun, S., Jones, C. \& Dunse, N. (2014). The Property Market Maturity Framework and its Application to a Developing Country: The Case of Nigeria. Journal of Real Estate Literature, 22(2), pp.217-223.

Aliyu, B.A., Sani, H., Usman, H. \& Muhammad, H. (2018). Ranking the Causative Factors of Mortgage Valuation Inaccuracy in Kaduna Metropolis. Real Estate Management and Valuation, 26(3), pp.71-91.

Aluko, B.T. (2007). Examining Valuers' Jugdement in Residential Property Valuations in Metropolitan Lagos, Nigeria. Property Management, 25(1), pp.98-107.

Ashaolu, T.A. \& Olaniran, M.O. (2016). Valuers' Strategies for Coping with the Dearth of Property Data in Two Nigerian Cities: Ibadan and Abeokuta. Pacific Rim Property Research Journal, 22(2), pp.167179.

Asobie, H.A. (1995). Centralising Trends in Nigerian Federalism. In: Nigerian Federalism 1990-1995. J. Isawa Elaigwu \& R. Akindele (Eds.) Abuja, FCT, Nigeria.

Awuah. K.G.B., Gyamfi-Yeboah, F., Proverbs, D. \& Lamond, J.E. (2017). Sources and Reliability of Property Market Information for Property Valuation Practice in Ghana. Property Management, 35(4), pp.448466. 
Ayedun, C.A., Oloyede, S.A. \& Durodola, O. (2012). An Empirical Study of the Causes of Valuation Variance and Inaccuracy. International Business Research, 5(3), pp. 71-79.

Babawale, G.K. \& Omirin, M. (2012). An Assessment of the Relative Impact of Factors Influencing Inaccuracy in Valuation. International Journal of Housing Markets and Analysis, 5(2), pp.145-160.

Bamigbola, D. (2018). International Standards and the Future of Real Estate Practice: The Need for a Property Databank. [Online]. Available at: http://eprints.covenantuniversity.edu.ng/10279/2/International\%20St andards $\% 20$ And $\% 20$ The $\% 20$ Future $\% 200 f \% 20$ Real $\% 20$ Estate $\% 20$ Practice $\% 20 \%$ E2\%80\%93\%20The $\% 20$ Need $\% 20$ For $\% 20$ Property $\%$ 20Databank.pdf (Accessed: 18 August, 2019).

Barkham, R., Bokhari, S. \& Saiz, A. (2018). Urban Big Data: City Management and Real Estate Markets. Urban Economics Lab MIT Center for Real Estate and DUSP. [Online]. Available at: https://mitcre.mit.edu/wp-content/uploads/2018/01/URBAN-DATAAND-REAL-ESTATE-JAN-2018-1.pdf (Accessed: 5 August, 2020).

Beguy, D. (2016). Poor Data Affects Africa's Ability to Make the Right Policy Decisions. [Online]. Available at:

https://theconversation.com/poor-data-affects-africas-ability-tomake-the-right-policy-decisions-64064 (Accessed: 29 September, 2019).

Bello, V.A. \& Thomas, O.J. (2015). Valuation Variance in the Commercial Property Market in Lagos, Nigeria. International Journal of Investment Management and Financial Innovations, 1(4), pp.105110.

Beresewicz, M. (2015). On Representativeness of Internet Data Sources for Real Estate Market in Poland. Austrian Journal of Statistics, 55, pp.120.

Burns, R.B. (2000). Introduction to Research Methods, London: SAGE Publications.

Butler, S. (2012). Nigeria's Land Markets and the Land Use Law of 1978. [Online]. Available at: www.focusonland.com/download/525525442d643 (Accessed: 12 August, 2018).

Butler, S.B. (2009). Improving Land Policy for Private Sector Development in Nigeria: Lessons and Challenges Ahead. Available at: https://www.siteresources.worldbank.org/INTIE/Resources/S_Butler doc. (Accessed: 13 August, 2018).

Calhoun, C.A. (2001). Property Valuation Methods and Data in the United States. Housing Finance International, 16(2), pp.12-23.

Chakravorti, B., Bhalla, A. \& Chaturvedi, R.S. (2019). Which Countries are leading the Data Economy? Harvard Business Review. [Online]. Available at: hbr.org $>2019 / 01>$ which-countries-are-leading-thedata-economy (Accessed: 9 October, 2020).

Clement, C.C., Ogunba, OA. \& Duggeri, T.T. (2016). An Evaluation of the Investment Maturity of Property Markets in Southwestern Nigeria. In proceedings of the $16^{\text {th }}$ AFRES Annual Conference, September, Tanzania. 
Darlow, C. (1982). Valuation and Development Appraisal. London: The Estates Gazette Limited

Economist. (2017). The World's Most Valuable Resource is Data, Not Oil. Economist. [Online]. Available at:

https://www.economist.com/leaders/2017/05/06/the-world's-mostvaluable-resource-is-no-longer-oil-but-data (Accessed: 9 July, 2020).

Effiong, J.B. (2015). A Comparative Study of Valuation Variance and Inaccuracy between Nigeria and the UK. International Letters of Social and Humanistic Sciences, 57, pp.94-105.

Fraser, W.D. (1984). Principles of Property Investment and Pricing. London: Macmillan Publishers Limited.

Gbonegun, V. (2018). Absence of National Property Databank Impeding Investment. The Guardian. [Online]. Available at: https://guardian.ng/property/absence-of-national-property-databankimpeding-investment. (Accessed: 5 July, 2020).

Ge, X.J. \& Harfield, T. (2006). The Quality of Data and Data Availability for Property Research. Unitec Research and Advanced Practice Committee for 2005 Internal Research \& Advanced Practice Fund (URAPC). [Online]: Available at:

http://www.prres.net/papers/Ge_Quality_\%20Data.pdf (Accessed: $15^{\text {th }}$ October, 2020).

Harvey, J. (1994). Economics Revision Guide. London: Palgrave https://doi.org/10.1007/978-1-349-133313-0_3.

https://www.jll.co.uk/en/trends-and-insights/research/global-realestate-transparency-index-2016 (Accessed:11 May, 2019). https://www.jll.co.uk/en/trends-and-insights/research/global-realestate-transparency-index (Accessed:11 May, 2019).

Ibiyemi, A.O. (2013). Market Risks Consideration by Commercial Property Investors and Valuers in Nigeria: The Critical Issues. The $27^{\text {th }}$ Inaugural Lecture of Lagos State Polytechnic, Ikorodu, Lagos. [Online]. Available at:

https://www.researchgate.net/publication/264314790_Market_Risks Consideration by Commercial Property Investors and Valuers i n_Nigeria_The_Critical_Issues (Accessed:14 August, 2013).

in an Opaque Market. Property Management, 37(1), pp. 82-96. https://doi.org/10.1108/PM-01-2017-0004.

ISPE. (2020). Good manufacturing practice (GMP) resources. International Society for Pharmaceutical Manufacturing. [Online]. Available at: https://ispe.org/initiatives/regulatory-resources/gmp (Accessed:13 July, 2020).

Jin, W., Zhou, C. \& Luo, L. (2018). Impact of Land Input on Economic Growth at Different Stages of Development in Chinese Cities and Regions. Sustainability, 10(2847), pp.1-19.

Jones Lang LaSalle. (2018). Global Real Estate Transparency Index 2018. [Online]Available at

Jones Lang LaSalle. (2016). Global Real Estate Transparency Index 2016. [Online]. Available at

Kazeem, Y. (2019). Flying Blind: African Governments need to fix their Problematic Relationship with Data on their own Countries. Quartz 
Africa. [Online]. Available at: www.qz.com/africa/1725537/africahas-a-data-problem (Accessed: 10 November, 2019).

Kelly, J. (2018). Why a Transparent Property Market Helps Cities Succeed.

World Economic Forum. [Online]. Available at: https://www.weforum.org/agenda/2018/10/transparent-real-estateproperty-market-successcities/\#: : text=Metropolitan $\% 20$ governments $\% 20$ and $\% 20$ public $\% 20$ bodies,role $\% 20 \mathrm{in} \% 20 \mathrm{a} \% 20$ city's $\% 20$ success.\&text=For $\% 20$ individu als $\% 2 \mathrm{C} \% 20$ transparency $\% 20$ means $\% 20$ they,and $\% 20$ reliable $\% 20$ an d\%20professional\%20services (Accessed: 2 June, 2020).

Kok, N., Koponen, E. \& Martínez-Barbosa, C.A. (2018). Big Data in Real Estate? From Manual Appraisal to Automated Valuation. Journal of Portfolio Management, Special Real Estate Issue, pp.202-211.

Kyenge J. (2013). The Challenges of Local Government Administration in Nigeria. Journal of Management and Corporate Governance, 5(1), pp.70-76.

Luus, C. (2003). The Absa Residential Property Market Database for South Africa-Key Data Trends and Implications. Bank for International Settlements. [Online]. Available at:

https://www.bis.org/publ/bppdf/bispap211.pdf (Accessed: 16 March, 2020).

McAfee, A. \& Brynjolfson, E. (2012). Big Data: The Management Revolution. Harvard Business Review, 90(10), pp.60-68.

Mends, T.M. (2006). Property Valuation in Ghana: Constraints and Contradictions. In proceedings of FIG Regional Conference on Promoting Land Administration and Good Governance. March, 2006. pp.8-11.

Minguzzi, G. (2014). The Role of Real Estate in the Economy. British Property Federation. [Online]. Available at: www.bpf.org.uk/aboutreal-estate (Accessed: 13th April, 2018).

Mutuku, L. (2016). The Big Data Challenge for Developing Countries. Third World Academy of Sciences. [Online]. Available at: https://www.twas.org/article/big-data-challenge (Accessed: 17 March, 2020).

Nigerian Institution of Estate Surveyors and Valuers (NIESV). (2020). About NIESV. [Online]. Available at:

https://www.niesv.org.ng/aboutus.php (Accessed:12 July, 2020).

Nwogu, E.C. (2006). Quality of Demographic Data in Nigeria: Problems and Prospects. Global Journal of Pure and Applied Sciences, 12(1), pp.99106.

Ogunba, A.O. \& Ajayi, C.A. (1998). An Assessment of the Accuracy of Valuations in the Residential Property Market of Lagos. The Estate Surveyor and Valuer, 21(2), pp.19-23.

Olaleye, A. (2004). A Case for a Property Data Bank in the Nigerian Property Market: An Empirical Study. The Estate Surveyor and Valuer, 27(1), pp.34-40.

Olaleye, A. (2008). Property Market Nature and the Choice of Property Portfolio Diversification Strategies: The Nigerian Experience. International Journal of Strategic Property Management, 12(1), pp.35-51. 
Olapade, D.T. \& Olaleye, A. (2019). Factors Affecting Accessibility to Data Olapade, D.T., Ekemode, B. \& Olaleye, A. (2019). Considerations for the Design and Management of a Property Database in Opaque Markets. Journal of Property Investment and Finance, 37(5), pp.445-454.

Olapade, T.O. \& Olaleye, A. (2018). Resolving the Data Debacle in Commercial Property: Are Property Practitioners in Opaque Markets Ready for Data Sharing and Assemblage? Journal of Property Investment and Finance, 36(3), pp.295-304. https://doi.org/10.1108/JPIF-07-2017-0054.

Olowofeso, O.E., Bada, A.S., Bamanga, M.A., Bassey, K.J. \& Dzaan, K.S. (2015). On the Development of Residential Property Price Indices for Nigeria. [Online]. CBN Journal of Applied Statistics, 3(2), pp.17-38.

Oloyede, S.A. (2011). Issues facing the Estate Surveying and Valuation Profession in Nigeria. Business Management Dynamics, 1(2), pp.5460.

Olubusoye, O.E., Keshinro, O. \& Korter, G. (2015). Nigerian Statistical System: Evolution, Progress and Challenges. [Online]. Available at: https://www.researchgate.net/publication/283715250 (Accessed: 11 July, 2020).

Özköse, H., Arı, E. S. \& Gencer, C. (2015). Yesterday, today and tomorrow of big data. Procedia-Social and Behavioral Sciences, 195, pp.10421050 .

Ronald Igbinoba Real Foundation for Housing and Urban Development. (2017). State of the Lagos housing market. [Online]. Available at: https://rirfhud.org/publications/ (Accessed: 17 September, 2018).

Savills UK. (2020). Property Management Services- Savills UK. [Online]. Available at: https://www.savills.co.uk/services/propertymanagement.aspx (Accessed:16 November, 2020).

Savills World Research. (2017). Trends in the World's Largest Asset Class. HSBC Global Real Estate Report 2017. HSBC Holdings plc.

Singh, P.J. (2019). Why Owning their National Data is Important for Developing Countries. IT for Change. [Online]. Available at: https://itforchange.net/sites/default/files/add/Why owning their nati onal data is important for developing countries.pdf (Accessed: 9 October, 2020).

Statista (2019a). Nigeria: Number of Online Users 2015-2025. [Online]. Available at: https://www.statista.com/statistics/183849/internetusers-nigeria/ (Accessed: 13 March, 2020).

Statista (2019b). Number of Social Network Users in Nigeria 2017-2025. [Online]. Available at: https://www.statista.com>statistics $>$ numbersof-social-network-users-in-nigeria (Accessed: 24 March, 2020).

The Partnership in Statistics for Development in the $21^{\text {st }}$ Century (PARIS21). In Development Co-operation Report 2015: Making Partnerships Effective Coalitions for Action, Paris: OECD Publishing. https://doi.org/10.1787/dcr-2015-21-en.

The Royal Institution of Chartered Surveyors (2017). The Future of Valuations. [Online]. Available at: https://www.rics.org/ssa/newsinsight/research/insights/the-future-of-valuations (Accessed: 9 July, 2020). 
The Royal Institution of Chartered Surveyors (RICS). (2019). The Use and Value of Commercial Property Data. [Online]. Available at: https://www.rics.org/globalassets/rics-

website/media/knowledge/research/insights/value-and-commercialproperty-data-rics.pdf (Accessed: 16 June, 2019).

Uduu, O. (2020). It's Time to Rethink Data Inadequacy and Weak Policies in Nigeria. Dataphyte. [Online]. Available at: https://www.dataphyte.com/development/its-time-rethink-data-ina. (Accessed:5 July, 2020).

Wallace, J. (2009, March). Making land markets work for all. Proceeding of the World Bank Conference on Land Governance in Support of the MDGs. Responding to New Challenges. Washington DC, USA. pp.910.

World Bank. (1989). World Development Report 1989: Financial Systems and Development. New York: Oxford University Press. (C) World Bank Group. [Online]. Available at:

https://openknowledge.worldbank.org/handle/10986/5972

(Accessed: 9 November, 2020).

World Bank (2018a). Literacy Rate, Adult Total (\% of people aged 15 and above: Sub-Saharan Africa. [Online]. UNESCO Institute of Statistics. Available at: https://data.worldbank.org/indicator/SE.ADT.LITR.ZS (Accessed: 16 June, 2020.

World Bank (2018b). Nigeria- World Bank Data. World Bank Group. [Online]. Available at: https://data.worldbank.org/country/NG (Accessed: 27 May, 2019).

Youngman, J. \& Malme, J. (2005). Stabilising Property Taxes in Volatile Real Estate Markets. Lincoln Institute for Land Policy. [Online] Available at:

https://www.lincolninst.edu/publications/articles/stabilizingproperty-taxes-volatile-real-estate-markets (Accessed: 9 October, 2020).

5CCPress. (2007). Privatization in Nigeria: In whose Interest? WordPress. [Online] Available at:

https://5ccpress.wordpress.com/2007/11/21/hello-world (Accessed: 20 December, 2015). 